\title{
USING SOIL SURVEYS TO PREDICT THE TYPE OF ONSITE WASTEWATER TREATMENT SYSTEM
}

\author{
A.C. Engebretson, E.J. Tyler*
}

\begin{abstract}
Limitation tables published in county soil survey reports for on-site wastewater treatment systems (OWTS) are for infiltration components installed $60 \mathrm{~cm}$ below the ground surface with $120 \mathrm{~cm}$ of unsaturated, unconsolidated permeable soil beneath the infiltrative surface. Users of limitation tables frequently apply the information to designs different than those used to develop the limitation ratings. The purpose of this research was to establish how well a soil survey could predict the design of OWTS. The location of 181 randomly selected OWTS was determined within a meter using a Sokkia Global Positioning System (GPS). Because locations were not recorded for unsuitable sites according to regulations, the probability of obtaining a permit by soil map units could not be determined. However, soils with systems rated as slight according to the limitations ratings were $89 \%$ in-ground systems and $11 \%$ above-grade, including mounds and at-grades. For soils rated as very severe, 22\% were inground and $78 \%$ above-grade. Data were evaluated using chi-squared analysis and $95 \%$ confidence intervals. The limitation ratings can be used to interpret in-ground system use. Since severe and very severe ratings are considered unsuitable for systems, it is generally believed no system can be used. However, above-grade systems are possible. A system incorporating all technical designs could reduce the misconception of the users. The limitation ratings predict the use of in-ground systems but are not designed to account for above-grade systems.
\end{abstract}

KEYWORDS. Land use, Soils, Wastewater disposal.

\section{INTRODUCTION}

A current land use topic involves on-site wastewater treatment systems. Most OWTS rely on soil for all or some wastewater treatment. Soil waste treatment success is dependent on chemical, physical and biological processes retaining, altering and transporting water and

\footnotetext{
*Work of Small Scale Waste Management Project and Dept. of Soil Science, University of WisconsinMadison, 1525 Observatory Drive, Madison, WI, 53706; 608-265-2595; www.wisc.edu/sswmp
}

In: K. Mancel (ed.) On-site wastewater treatment. Proc. of the $9^{\text {th }}$ International Symposium on Individual and Small Community Sewage Systems. ASAE. St. Joseph, MI. P.116-124

Andrea C. Engebretson is Manager of Professional Education, American Society of Agronomy, 677 S. Segoe Road, Madison, WI, 53711, formerly Research Assistant, Dept. of Soil Science and Small Scale Waste Management Project, University of Wisconsin-Madison.

E. Jerry Tyler is Professor of Soil Science and Director of the Small Scale Waste Management Project, University of Wisconsin-Madison, 1525 Observatory Drive, Madison, WI 53706; ejtyler@facstaff.wisc.edu. 
pollutants. Other uses of land are also dependent on soil characteristics. Since the uses of soil depend on soil characteristics and soil maps are based on sets of soil characteristics, the success of given land uses for different locations can be predicted by comparing the soil characteristics of the land use and the soil characteristics of locations based on soil maps. Therefore, soil maps should be able to be used to predict the success of technical applications, and technically suitable land use.

The reliability of matching soil characteristics from the soil map and soil characteristics for land uses depends on the quality of the soil survey map, knowledge of the land use and the ability to integrate the two. The focus of soil map research has been precision and accuracy of the maps. Studies have found the purity of the soil mapping unit to range from $<30 \%$ to $>80 \%$. This range is a potential obstacle for users who are trying to integrate land use with soil characteristics unless the accuracy of a specific region is defined within narrower limits (Amos and Whiteside, 1975; Arnold, 1996; Brown, 1985; Brown, 1988).

As non-technical users increase, the need for improved definitions, explanations, and interpretations of similar and contrasting soils increases (Brown and Huddleston, 1991). The literature available on the reliability of the interpretative tables is limited, and very little work has been done to statistically verify the information in the interpretative tables (Brown and Huddleston, 1991). To ease the misuse of soil survey information, Brasher and Benham (1996) suggest the use of a system that would rate the quality of the soil survey information and include ratings with the data.

The goal of this research was to quantify the reliability of two soil interpretation rating systems for predicting OWTS suitability in Dane County, Wisconsin -- the Soil Survey of Dane County and the State rating system.

\section{MATERIAL AND METHODS}

\section{$\underline{\text { Study Location }}$}

The study area was Dane County, Wisconsin. The physical geography of the region was affected by the Wisconsin glaciation 14,000 to 18,000 years ago. The western quarter of the county, the driftless region, was left unscathed by the glaciers and therefore has an older landscape with discernable landscape patterns of wind and water eroded bedrock. The landscape in the eastern three-quarters of the county has been detailed with moraines, drumlins, lakes and wetlands (Dane County Regional Planning Commission, 1998).

Occupying 1,230 square miles and located in south central Wisconsin, Dane County is home to 398,233 people making it the second most populated county in the state. The city of Madison is located in the center of the county. Over 19,000 homes are being served by OWTS in Dane County, Wisconsin. By 2020, that number will rise to an estimated 26,000 (Dane County Regional Planning Commission, 1998). From 1990 to 1997, 4999 permits for conventional, at-grade, and mound systems were issued in Dane County. Of these permits, 
1466 were for mound and at-grades; systems not considered in the soil survey suitability tables (Dane County Department of Environmental Health, 1998).

For this study, 25 of 35 townships were randomly selected. To avoid a biased and unrepresentative sample, townships were chosen from both the driftless and glaciated regions of the county. The number of townships selected in each region was based on the number of townships and total area affected by the Wisconsin glaciation; $25 \%$ of the selected townships were in the driftless region and $75 \%$ were in the glaciated region.

Property address, owner's name, soil description, allowable system and system design, are on file for every OWTS plan in Dane County. These public records were available at the Dane County Department of Environmental Health. Each OWTS plan is organized by township and then by section number. The plans in each township section are not in alphabetical or chronological order. This contributes to the randomness of the site collection. Each township has 36 sections.

Twenty percent of the OWTS plans and permits for the selected 25 townships were sampled by recording every fifth site on file. Only OWTS plans with soil descriptions were used in this study. Plans were selected starting in 1990 because it was a grace year where both percolation tests and soil descriptions were accepted.

Once plans were selected, property owners were contacted. Permission was asked of the property owner if researchers could determine the location of the owners' drainfields, mounds, or at-grades by standing on the systems while using a global positioning system (GPS) with $0.8 \mathrm{~m}$ accuracy (Ashtech, July 1997). Individuals' responses were categorized into 3 groups: positive, negative and none.

\section{$\underline{\text { Data Management and Analysis }}$}

Geographical information system (GIS) software was used to import the collected GPS shape files. The soil survey map was the bottom layer on which the collected GPS points of the OWTS were overlayed.

The overlayed points were compared to the underlying soil map units of the digitized Dane County Soil Map (based on the published Dane County Soil Survey 1:15,840) using the soil attribute table attached to the digitized map. The Soil Survey of Dane County and the State rating system combine specified soil characteristics to create a rating scheme for each soil mapping unit--either slight, moderate, severe, or very severe for the soil survey or high, moderate, low or very low for the State rating. The soil mapping unit from the digitized soil survey map was referenced to the published soil survey table and the corresponding rating of slight, moderate, severe or very severe was recorded. The soil mapping unit was also compared to the state rating categories. Two sampling rounds were conducted.

The Natural Resource Conservation Service (NRCS) of the United States Department of Agriculture (USDA) has established a table of soil limitations. The limitations are designed only for an in-ground wastewater infiltration (Soil Survey Staff, 1993). Soil characteristics as 
identified and mapped in soil surveys from $60 \mathrm{~cm}$ to $180 \mathrm{~cm}$ below the ground surface, the zone of wastewater treatment, are compared with soil characteristics important for wastewater treatment. The table is used as the basis to make technical classifications of slight, moderate, severe, and very severe, as published in the soil survey reports, for each soil mapped (Table 1). Slight suggests the soil properties are favorable for the in-ground system installation, and any limitations can be easily overcome. A very severe rating means one or more soil properties are unfavorable for the OWTS installation and overcoming the limitation would be uneconomical or impractical (Soil Survey Staff, 1978).

The USDA Natural Resource Conservation Service (USDA-NRCS) Wisconsin office in cooperation with the Wisconsin Department of Commerce and the Small Scale Waste Management Project of the University of Wisconsin organized a new rating system that utilizes soil survey information including depth to bedrock, slope, permeability, wetness and flooding. However, this system does not limit the information to $60-180 \mathrm{~cm}$ below ground allowing mound and at-grade systems to be included in its rating scheme (Table 2). This rating system will be referred to as the State rating system. The state rating system estimates the probability of either an in-ground, at-grade or mound installation for the mapped soil. Points are assigned for each soil limitation. The more points assigned to a soil, the lower the probability of an OWTS. Ratings of high, moderate, low and very low are used. High indicates a high probability of finding a suitable area in the mapping unit for an in-ground, atgrade or mound installation. A rating of very low indicates a very low probability of OWTS installation. In addition to estimating the probability rating of the soil mapping unit, the state rating system also predicts the kind of system most likely suitable for the site.

Table 1. Soil Interpretation Rating Guides for Septic Tank Absorption Fields (Soil Survey Staff, 1993).

\begin{tabular}{|c|c|c|c|c|}
\hline & \multicolumn{3}{|c|}{ Limits } & \multirow{2}{*}{$\begin{array}{l}\text { Restrictive } \\
\text { Feature }\end{array}$} \\
\hline Property & Slight & Moderate & Severe & \\
\hline USDA Texture & --- & --- & Ice & Permafrost \\
\hline Total Subsidence & --- & --- & $>24 "$ & Subsides \\
\hline Flooding & None & Rare & $\begin{array}{l}\text { Frequently or } \\
\text { occasionally }\end{array}$ & Flooding \\
\hline Depth to Bedrock $(\mathrm{cm})$ & $>183$ & $102-183$ & $<102$ & Depth to Rock \\
\hline Depth to Cemented Pan $(\mathrm{cm})$ & $>183$ & $102-183$ & $<102$ & Cemented Pan \\
\hline Ponding & --- & $\begin{array}{ll}--- \\
\end{array}$ & + & Ponding \\
\hline $\begin{array}{l}\text { Depth to High Water Table } \\
\text { (m) }\end{array}$ & $>2$ & $1-2$ & $<1$ & Wetness \\
\hline $\begin{array}{l}\text { Permeability } \\
(61-152 \mathrm{~cm} / \mathrm{h})\end{array}$ & $5-15$ & $2-5$ & $<2$ & Percs slowly \\
\hline Slope $(\%)$ & $<8$ & $8-15$ & $>15$ & Slope \\
\hline $\begin{array}{l}\text { Weight percent }>8 \mathrm{~cm} \\
\text { (Weighted av. to } 102 \mathrm{~cm} \text { ) }\end{array}$ & $<64$ & $64-127$ & $>127$ & Large Stones \\
\hline
\end{tabular}


Table 2. Soil Probability of Meeting State Code for Septic Tank Filter Fields Rating Guide (USDA, 1997).

\begin{tabular}{|c|c|c|c|}
\hline Limitation & Limits & $\begin{array}{l}\text { (Type of } \\
\text { System) } \\
\text { Below Grade } \\
\text { Gravity }\end{array}$ & Points \\
\hline Slope & & & 0 to 5 \\
\hline Bedrock $(\mathrm{cm})$ & $\begin{array}{l}\text { Rockdeph }<=76 \text { (not soft sandstone) } \\
\text { Rockdeph }>76 \&<=142 \text { (not soft sandstone) }\end{array}$ & & 0 to 8 \\
\hline Wetness $(\mathrm{cm})$ & $\begin{array}{l}\text { Wtdepl }>=1.4 \\
\text { Wtdeph }<=1 \text { and wtkind = APPAR } \\
\text { Wtdeph }<=1.4 \\
\text { Other soils }\end{array}$ & $\begin{array}{l}\text { Yes } \\
\text { No } \\
\text { No } \\
\text { May }\end{array}$ & $\begin{array}{l}0 \\
5 \\
3 \\
1\end{array}$ \\
\hline Permeability & $\begin{array}{l}\text { Does NOT have a layer at least } 91 \mathrm{~cm} \text { thick } \\
\text { between } 51-132 \mathrm{~cm} \text { containing no bedrock } \\
\text { (except soft sandstone) and with permh }>=1.5 \text { in } \\
\text { All parts } \\
\text { HAS a layer at least } 9 \mathrm{~cm} \text { thick, beginning } \\
\text { between } 51-132 \mathrm{~cm} \text { containing NO bedrock } \\
\text { (even soft sandstone) and with perml }>=0.5 \text { in } \\
\text { ALL parts and }<46 \mathrm{~cm} \text { of this layer is projected } \\
\text { As above, except }>=46 \mathrm{~cm} \text { is projected or layer } \\
\text { contains soft sandstone } \\
\text { Other soils with }<46 \mathrm{~cm} \text { projected } \\
\text { Other soils with }>=46 \mathrm{~cm} \text { projected } \\
\text { - If perml }<=0.5 \text { in any part of the suitable } \\
\text { layer, may need a larger system } \\
\text { If most of the suitable layer is rapidly } \\
\text { permeable, may be leaching }\end{array}$ & $\begin{array}{l}\text { No } \\
\text { Yes }\end{array}$ & $\begin{array}{l}1 \\
1 \\
2\end{array}$ \\
\hline Flooding & $\begin{array}{l}\text { None } \\
\text { Rare } \\
\text { Occasionally, common, or freq only } \\
\text { Other soils }\end{array}$ & $\begin{array}{l}\text { Yes } \\
\text { May } \\
\text { No } \\
\text { May }\end{array}$ & $\begin{array}{l}0 \\
1 \\
5 \\
2\end{array}$ \\
\hline $\begin{array}{l}\text { Unsuitable } \\
\text { soil or site }\end{array}$ & $\begin{array}{l}\text { Beaches, pits, urban land, dams, quarries, rubble } \\
\text { land, seepage land }\end{array}$ & No & 5 \\
\hline
\end{tabular}

\begin{tabular}{|l|l|l|l|l|}
\hline Probability rating & High & Moderate & Low & $\begin{array}{l}\text { Very } \\
\text { Low }\end{array}$ \\
\hline Total Points & 0 & 1 or 2 & 3 or 4 & $>=5$ \\
\hline
\end{tabular}


An assessment of the validity of the collected GPS data points and stated hypotheses was completed using a standard chi-squared analysis (Nordheim and Clayton, 1996). Tests for true proportions of OWTS observed were computed for a range of true proportions and the $95 \%$ confidence interval included all the values that were not rejected at $\alpha=0.05$.

\section{RESULTS AND DISCUSSION}

Plans for 897 systems were randomly selected from the 4999 plans submitted between 19901997. It was not possible to select exactly $20 \%$ of the systems because the records were removed, periodically, by the staff of the Dane County Department of Environmental Health. Of the 897 selected sites, 296 property owners granted permission to obtain coordinate data for their property, 182 sites were sampled. Not all 296 sites were sampled because of difficulties with equipment, weather, and system locations.

Using chi-squared analysis to analyze response bias by glaciated and driftless regions, no biases were present $(p=0.141)$. However, a response bias was by system type $(p=0.011)$. A larger proportion of negative responses were from owners of above ground systems; therefore fewer above ground systems were available for sampling. The high negative response rate may be explained by the higher cost of installing these systems along with anecdotal evidence of frustration by the property owners with the entire process of obtaining a permit, installation and any additional problems.

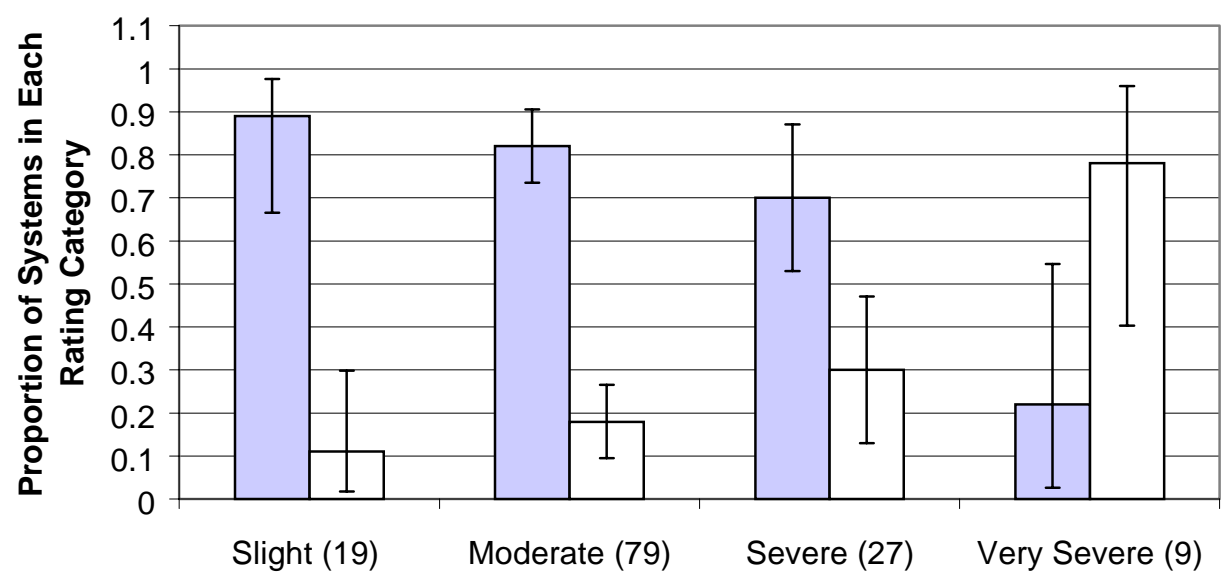

Soil Survey Ratings for In-ground and Above Ground Systems

$\square$ Conventional $\square$ Above Ground

Figure 1. Proportion of In-ground and Above Ground Systems for Each Soil Survey Category.

\section{$\underline{\text { The Soil Survey Data }}$}

The data collected from the files at the Dane County Department of Environmental Health only reflect soils that passed the permitting process. No soils that failed the permitting process were recorded. Without the information on failures, this study cannot make statements 
about the probability of acquiring an OWTS permit. However, once a permit has been approved, the data generated in this study can offer probabilities as to the type of system that will be installed.

Two hypotheses were tested. One considered if the type of OWTS installed changed with the type of soil rating in the Soil Survey of Dane County. The second considered if the type of OWTS installed changed with the type of soil rating provided by the State. For example, when the soil mapping unit was designated as severe by the soil survey or low by the State system were there an equal proportion of mound, at-grades and conventional systems installed? The same question was asked when the soil mapping unit was rated slight or high.

Figure 1 displays data collected only in the first sampling round and is organized according to soil ratings designated by the Soil Survey. The numbers in parentheses along the $\mathrm{x}$-axis are the number of OWTS observed in soils with each rating category. For example, 19 OWTS sites were in or on soil mapping units with a Soil Survey rating of "slight". Of the 19 sites with a slight rating, 17 had conventional systems installed. The other 2 sites needed above ground systems. The interval bars around the graphed points represent the $95 \%$ confidence interval.

As the soil ratings become more severe, the proportion of above ground systems increase and conventional systems decrease. These proportions do not follow the Soil Survey's original intent. "Severe" as described in the soil survey suggests the soil is "so difficult to correct...as to require major soil reclamation", yet $70 \%$ of the sites located in severe soil were conventional systems (fig. 1).

While the proportion of conventional systems was declining, the proportion of above-grade systems was increasing. The Soil Survey rating system is not designed to consider above ground systems, yet $42 \%$ of the systems installed in soil rated as severe and very severe are above ground systems (fig. 1).

A chi-squared analysis for the Soil Survey hypothesis generated a p-value of 0.0003 . The low p-value reflects a decline in the proportion of conventional systems as the soil characteristics for in-ground systems become more severe while the proportion of above ground systems for the same rating increased. The small $\mathrm{p}$-value generated by the chi-squared analysis signifies an unequal proportion of OWTS for the soil survey ratings of slight, moderate, severe and very severe.

These findings are not surprising since a soil with a very severe rating signifies a limiting condition that would prevent the use of a conventional system. A mound or at-grade system, both above ground, was not expected to be installed on a soil with few limiting conditions. Since above ground systems are more expensive, below ground systems are the first choice when existing soil conditions are suitable for their installation.

The second hypothesis examines the proportion of OWTS installed in or on soils with State ratings of high, moderate, low and very low. As in the first hypothesis, the second hypothesis states that an equal proportion of OWTS are in each rating category of high, moderate, low 
and very low. The collected data are displayed according to State ratings in fig. 2. The numbers in parentheses signify the number of systems installed in or on soils rated with the State's categories. Of the 108 systems installed in soils rated as "high", 90 were conventional and 18 were above ground.

Soils rated as high or moderate had 100 conventional systems and 23 above ground systems. Three conventional and 8 above ground systems were installed in soils rated as low and very low. As the probability of acquiring a permit for OWTS installation decreases, the proportion of conventional systems installed decreases and above ground systems increases (fig. 2).

A p-value of 0.00028 generated from a chi-squared analysis indicates that the proportion of above ground and conventional systems for each state rating category are not equal. The proportions of below grade systems declined when the State ratings were low and very low. The proportions for above grade (i.e., at-grade and mound) systems steadily increased in the State rating as the probability ratings lowered.

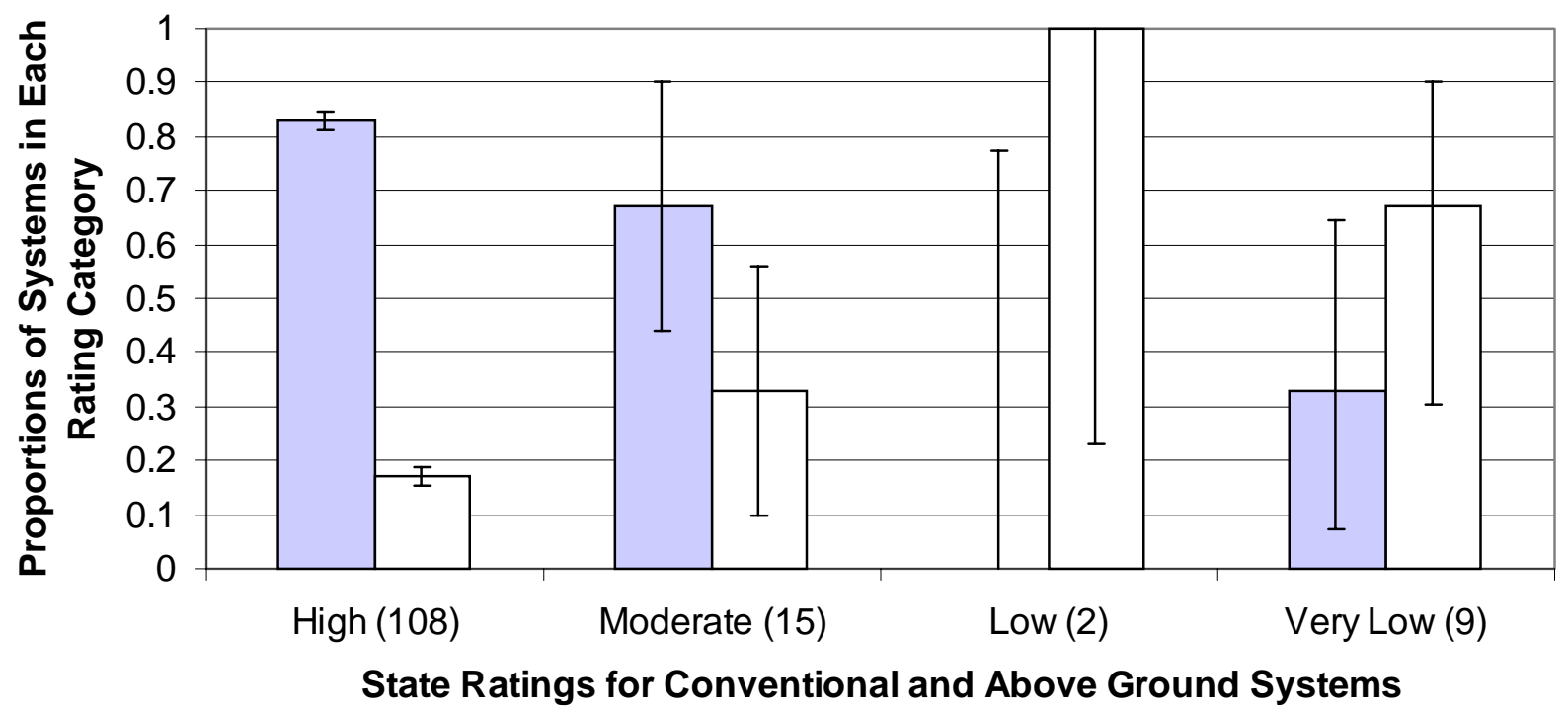

$\square$ Conventional $\square$ Above Ground

Figure 2. Proportion of In-ground and Above Ground Systems for Each State Rating Category.

These findings echo what occurred with the Soil Survey data. The low and very low categories signify the reduced probability of the soil map unit to contain a suitable site for an OWTS. With the low and very low probability, one would expect to observe fewer conventional systems on these sites, however above grade systems (at-grade and mounds) can overcome some of the limiting conditions and can still be installed. 


\section{CONCLUSIONS AND RECOMMENDATIONS}

The Soil Survey rating criteria for septic tank absorption fields works well when predicting conventional system installation. The data found $89 \%$ of conventional systems were in soils rated as slight. However, the Soil Survey and limitation tables do not work as intended when considering other technology. Seventy eight percent of above ground systems were in very severe soils. These findings are logical, as the soil conditions become more severe and limiting one applies technology to overcome the limitations. The designation of "very severe" states that soil properties are unfavorable for OWTS installation and overcoming limitations would be impractical. The purpose of the "very severe" rating is to designate soil with characteristics unsuitable for OWTS installation. However, the proportion of above ground systems increased as the Soil Survey rating became more severe.

Many on-site wastewater treatment system designs are used today. The technology is constantly changing and acceptance of different designs can vary by state, county and township. Direct application of the Soil Survey does not work well, if used as described, when considering a myriad of other technologies. However, suggestions can be made to improve its reliability among users. To prevent misapplication of the Soil Survey for OWTS installation, specification as to what type of treatment system is considered in the ratings should be stated clearly above the tables. This would be an easy short term remedy to help users of the information recognize soil ratings do not apply to alternative systems (i.e., atgrade and mound).

These data offer planners probability statements once a permit for OWTS installation has been granted. If the soil is rated as slight and has passed the permitting process, $89 \%$ of the time a conventional system will be installed. Conversely, if the soil passed the permitting process and is rated as very severe, a system can still be installed. The system, $78 \%$ of the time, will be an above ground.

To improve the user-friendliness of the Soil Survey for long-term use, slight, moderate, severe and very severe should be discontinued. Instead, probabilities for system categories should be offered. For example, in place of "slight", a range and statement of 80-95\% of permitted systems installed will be in-ground, should be provided for a soil mapping unit.

These data do not support the use of Soil Survey septic ratings as intended for land use predictions. To make land use predictions, data on soils where septic permits were denied would need to be evaluated.

Research needs to be conducted comparing soils where septic systems pass the permitting process and soils where septic systems are denied installation. For planners who are recommending land use choices, the soil survey can be a valuable tool once the intentions of the survey are clearly specified. Additional statistical and scientific data can now be added to the philosophical and political arguments surrounding land use. 


\section{REFERENCES}

1. Amos, D.F. and E.P. Whiteside. 1975. Mapping accuracy of a contemporary soil survey in an urbanizing area. Soil Sci. Soc. Am. Proc. 39: 973-942.

2. Anderson, J.L. and J. Bouma. 1977. Water movement through pedal soils. II. Unsaturated flow. Soil Sci. Soc. Am. Proc. 41: 419-423.

3. Arnold, R.W. 1996. Soil survey reliability: Minimizing the consumer's risk. p. 13-20. In: SSSA Special Publ. 47. Soil Science Society of America, Madison, WI.

4. Ashtech. 1997. GIR 1000 Huskey Field Operations Manual.

5. Brasher, B.R. and E. Benham. 1996. Quality assessment of soil survey information. p. 21-31. In: SSSA Special Publ. 47. Soil Science Socieyt of America, Madison, WI.

6. Brown, R.B. 1985. The need for continuing update of soil surveys. Florida Soil Crop Sci. Soc. 44 : 90-93.

7. Brown, R.B. 1988. Concerning the quality of the soil survey. J. Soil Water Conserv. 24: 452-455.

8. Brown, R.B. and J.H. Huddleston. 1991. Presentation of statistical data on map units to the user. p. 127-147. In: Soil Science Society of America Publ., Madison, WI.

9. Dane County Regional Planning Commission. 1998. On-site wastewater systems management program: Draft document for review. Madison, WI.

10. Dane County Department of Environmental Health. 1998. New and replacement sanitary permits issued 1990-1997. Madison, WI.

11. Nordheim, E.V. and M.K. Clayton. 1996. Course notes for Statistics 571. Department of Statistics, University of Wisconsin-Madison.

12. USDA, Soil Conservation Service. 1993. National soil survey handbook. Title 430-VI. Washington, DC.

13. USDA, Soil Conservation Service. 1978. Soil survey of Dane County, WI.

14. USDA, Natural Resources Conservation Sevice. 1997. Soil rating for private on-site wastewater treatment systems, Dane County, WI. (Draft). 